\title{
THE RESOLUTION OF THE EUROPEAN PARLIAMENT ON THE STRATEGIC COMMUNICATIONS IN THE CONTEXT OF THE RIGHT TO FREEDOM OF EXPRESSION AND RUSSOPHOBIA ${ }^{* *}$
}

\begin{abstract}
In November 2016, the European Parliament passed the resolution "EU Strategic Communications to Counteract Propaganda against It by Third Parties". In this resolution, initiated by Polish deputy Anna Fotig, Russia is equated with the terrorist Islamic State, while Russian media, like RT and Sputnik, are listed in a totalitarian manner as "unacceptable". The resolution is in legal conflict with Article 10 of the European Convention on Human Rights and Article 11 of the Charter of Fundamental Rights of the European Union, which have guaranteed freedom of expression and information on the European soil since 1953. It is also in violation of the universal international conventions, such as: the UN Charter, the Universal Declaration of Human Rights and the International Covenant on Civil and Political Rights. Therefore, it must be viewed in the context of politically motivated sanctions that the UN introduced against the Russian Federation in 2014.
\end{abstract}

Keywords: European Parliament, EU, freedom of expression, Russian Federation.

\section{Freedom of expression as a fundamental human right}

Human rights have become one of the fundamental part of the international public law after 1945 (Kreća, Paunović, 2002: 246). In theory, it is considered that their significance sometimes surpasses agreements as sources, and that certain international human rights have become common law rules, such as the right

\footnotetext{
*dejan.mirovic@pr.ac.rs

${ }^{* *}$ This paper was presented at the International Scientific Conference "Law in the context of addressing the Challenges of the Contemporary World", held at the Faculty of Law, University of Niš, on $13^{\text {th }}-14^{\text {th }}$ April 2018.
} 
to life (Milisavljević, 2016: 98). In that context, their appearance is connected to much older sources and events, such as the American or French revolution, while the division of human rights into the so-called "three generations" is done according to the time of their emergence.

According to legal theory, the right to freedom of expression belongs to those human rights which protect the social and moral integrity of a person (Paunović, Krivokapić, Krstić, 2010: 201-232). It originates from the freedom of thought, as well as from the freedom of religion. If those fundamental human rights are guaranteed in a society, then the right to freedom of expression is derived from them (Hanski, Šajnin 2007: 285). The distinction is that the freedom of expression is closer to the public law than the right of the freedom of thought, as well as the freedom of religion, which is primarily connected with private law. The right to freedom of expression can have an oral or a written form. However, the right to freedom of expression is not only an individual right. According to legal theory, which is mainly based on the international codifications after 1945 and the practice of the European Court of Human Rights, the freedom of expression is guaranteed to the minority groups. They can be a minority not only in the ethnical sense but also in the political and religious sense. The freedom of expression is a contribution to the open public debate, but it also guarantees the freedom of the oppositional opinion and the work of electronic and printed media as well.

The main sources of freedom of expression are: Article 19 of the Universal Declaration of Human Rights, Article 19 of the International Covenant on Civil and Political Rights, and Article 11 of Charter of Fundamental Rights of the European Union. In addition, Recommendation No. R (97) 20 of the Committee of Ministers of the Council of Europe guarantees the freedom of expression referring to the Declaration of the Heads of State or Government of the member states of the Council of Europe adopted in Vienna on $9^{\text {th }}$ October 1993, as well as the Declaration on the Freedom of Expression and Information of $29^{\text {th }}$ April 1982 and the Declaration on Media in a Democratic Society, adopted at the Fourth European Ministerial Conference on Mass Media Policy in Prague on $7^{\text {th }}-8^{\text {th }}$ December 1994.

All these sources guarantee the freedom of expression at the European and universal level. The freedom of expression also comprises obtaining information from various sources, which are mutually conflicting.

\section{Cold-war context of adopting Article 10 of the European Convention on Human Rights}

The European Convention for the Protection of Human Rights and Fundamental Freedoms (hereinafter: the European Convention on Human Rights, the ECHR) 
was adopted in 1950, and came into force in 1953. In the Cold-war context, it was undoubtedly a means in the political battle between the two world blocks. The West fiercely criticized the lack of freedom of expression in the USSR and the significance of human rights was to be expanded. At the same time, the then Russia was presented as a totalitarian country where it was not possible to hear a different opinion. Such theses were even presented by some of the most influential American Neo-Marxists such as Herbert Marcuse. The West allegedly allowed the freedom of expression even though there was a "good" kind of the restriction of the freedom of expression in that part of the world. Those were the restrictions behind which the "liberal" goals lay (Marcuse, 1983: 29, 38, 42, $46-47,49,157,167,220)$. Moscow, on the other hand, consciously deprived people of their freedom, whereas in the West, it was happening "unintentionally". In the West, the dominant ideas are the ones of the freedom of ethics and Christianity. Western civilization has "ideas", and Russian/Soviet civilization does not. Western civilization was created in search of "the truth"'. In the West, there is a consensus between the intellectuals of all kinds (from Bentham to Saint-Simon) that the actual system is the best possible. The West is dominated by idealism, and Russia is dominated by the utilitarianism of the mind. In the West, people have been diligent for generations; in Russia, they were forced to be diligent by communism (Marcuse, 1983: 12, 16, 21, 23, 26, 27, 29, 32-33, 35-36, 40, 47, 50, $54,58,59,62,68,70-71,86-87,91-99,108,119,138,152,178-179,184,193$, $215,217,222,232)$. In the West, the press "censures itself"'. The West is a society of happiness and neo-colonialism, and the USSR is a society of totalitarianism or "terrorism"; (this was, by the way, stated for the country that was a founder of the UN). That is why the western society is a "rational totalitarian society"' in which there is a rational limitation of the freedom of expression.

In the Cold-war and Soviet-phobia context which symbolizes the consensus of left-wingers like Marcuse and right-wingers like the American senator McCarthy, the European Convention on Human Rights (ECHR) was adopted in 1950, including its well-known Article 10 which guarantees the freedom of expression. Article 10 ECHR states: ${ }^{1}$

1. "Everyone has the right to freedom of expression. This right shall include freedom to hold opinions and to receive and impart information and ideas without interference by public authority and regardless of frontiers. This article shall not prevent States from requiring the licensing of broadcasting, television or cinema enterprises.

1 Art.10 ECHR The European Convention for the Protection of Human Rights and Fundamental Freedoms (hereinafter: the European Convention on Human Rights, the ECHR) was adopted in 1950, and came into force in 1953 
2. The exercise of these freedoms, since it carries with it duties and responsibilities, may be subject to such formalities, conditions, restrictions or penalties as are prescribed by law and are necessary in a democratic society, in the interests of national security, territorial integrity or public safety, for the prevention of disorder or crime, for the protection of health or morals, for the protection of the reputation or rights of others, for preventing the disclosure of information received in confidence, or for maintaining the authority and impartiality of the judiciary."

Also, Article 17 of the Convention emphasizes that: "Nothing in this Convention may be interpreted as implying for any State, group or person any right to engage in any activity of perform any act aimed at the destruction of any of the rights and freedoms set forth herein or at their limitation to a greater extent than is provided for in the Convention". So, the West is using the freedom of expression as a means in the Cold War against Moscow. The field of this battle is the European continent. The intellectuals such as Brodsky, Sakharov or Solzhenitsyn were awarded Nobel Prizes and the asylum in the West because they were deprived of human rights, primarily the right to the freedom of expression. The Conference on Security and Co-operation in Europe held in Helsinki in 1975 was another impetus for spreading human rights to the East.

\section{The practice of the European Court of Human Rights (ECtHR)}

The European Court of Human Rights (ECtHR) and the European Commission for Human Rights have developed large practice in the settlement of disputes concerning the interpretation of Article 10 of the European Convention or the interpretation of the freedom of expression. In the well-know case Jersild v. Denmark, the European Court of Human Rights decided that: "Freedom of expression constitutes one of the essential foundations of a democratic society; and these principles are of particular importance as far as the media are concerned... it is incumbent on the media to impart information and ideas on matters of public interest, and the public also has a right to receive them. Were it otherwise, the media would be unable to play their vital role of public watchdog". ${ }^{2}$ The Court is of the opinion that it is neither their right, nor the right of the national courts, to impose the media their own stand which technique the media should use in their reporting, and they highlight that Article 10 also protects the form in which information and ideas are presented. So, the European Court of Human Rights concluded in the Jersild case in 1994 that the freedom of expression, the availability of information on the important social matters, the observance of

2 Jersild v Denmark (App no 15890/89) ECHR 23 September 1994, European Court Of Human Rights, http://www.hr-dp.org/files/2013/09/09/CASE_OF_JERSILD_v._DENMARK_.pdf 
the overall context in which the declarations were made, and the awareness of the viewers and listeners are the primary criteria for the decision whether somebody abused the freedom of expression.

The decisions of the European Commission for Human Rights from 1994 and 1997 could be observed in the same context. For example, according to the application No. 18714/91, in their Decision of $9^{\text {th }}$ May 1994 on the case Brind et al. $v$. United Kingdom (the prohibition of live broadcast of the interview or statements of persons who openly express their support to organizations connected with Sinn Féin), the Commission concluded that the prohibition of the interview is unacceptable. The same conclusion was reached in the application No 18759/91, the Decision of $9^{\text {th }}$ May 1994 on the prohibition of the live television broadcasting of the interview or the statements of persons who openly express their support to organizations connected with Sinn Féin, as well as in connection with the applications No. 28979/95 and 30343/96, the Decision of $13^{\text {th }}$ January 1997 in the case G. Adams and T. Ben v. United Kingdom concerning the prohibition expressed to the president of Sinn Féin to come to England after the invitation of some members of Parliament and journalists.

Thus, the European Court has actually enabled the court practice to be one more source that guarantees the freedom of expression on the Continent.

\section{Russophobia and the borders of the freedom of expression 2014-2017}

However, after the outbreak of the Ukrainian crisis in 2014, a great change happened. The line between the freedom limitation and the hate speech was erased. The Russians were depicted as barbarians and terrorists, dangerous aggressors who jeopardize the "enlightened" West and its "values" in both military and propaganda terms; they "falsify" the history for the sake of their "imperial" interests; they are led by "unbalanced" and perverted people who attack other countries, and inside Russia itself "despotism" rules.

In that ideological discourse, the influential German weekly newspaper, The Spiegel, in 2016, depicted Russia as "Upper Volta with nuclear projectiles". ${ }^{3}$ The Anglo-Saxon media and elite often lack the elementary politeness when they talk about Russia. A reporter from Fox television (Bill O'Reilly) in his interview with the American President in February 2017 openly claims that the Russian

3 See: Wiegrefe K. "NATO Efforts to Boost Force in Baltics Will Not Boost Security", Spiegel, 12/7/2016 http://www.spiegel.de/international/world/nato-efforts-to-boost-force-in-balticswill-not-boost-security-a-1102578.html (accessed 1/9/2017); Lucas E."'We must stand up to Putin's gangster state.", The Times, 22/12/2016, https://www.thetimes.co.uk/article/ we-must-stand-up-to-putins-gangster-state-lclxflz9j (accessed 1/9/2017) 
president is a killer: "He’s a killer, though. Putin's a killer."4 (For British media, the Russian president is a "paedophile").

For the US ambassador in the UN, Samantha Power, Russian actions in Syria are "barbarism" (even though the Russian forces act in that area on the bases of the invitation of the legitimate leaders, unlike the Western coalition). "What Russia is sponsoring and doing is not counter-terrorism, it is barbarism."6 British Prime Minister Theresa May in 2016 warned that the whole Europe was allegedly "at the height of the Russian aggression" (even though British troops were stationed in the Amari base in the north of Estonia, about 130 kilometres from the Russian border), and required the unification of Europe against the "gruesome Russian aggression". ${ }^{7}$ Russia is an "existential threat" not only for Europe but for the whole world's order, claimed the former Chief Commander of the NATO forces in Europe, Philip Breedlove, in the magazine Foreign Policy in June 2016. Not only is the official Russia an enemy. The "problematic" ones are even Russian monks. As "revealed" by a British portal Spectator in September $2016,{ }^{8}$ they allegedly use Mount Athos as a spy and propaganda centre. Namely, the Russians have a "secret plan" carried out by about 70 monks (even though the British reporter "has his doubts" that there are ten times more of them) from the Russian monastery St. Panteleimon. A "non-holy alliance" was created between the monks and the Russian president (or the former KGB agent), claim the British media. The aim of that "non-holy alliance" is to undermine the NATO and the EU, as well as the "circumvention" of the Dardanelles. The "proof" for this are the satellite and television antennas situated in the Russian monastery.

4 When the spokesperson of the Russian president requested the apology, the reporter cynically replied that he would wait until 2023, "Bill O'Reilly: Putin will have to wait for apology over 'killer' remark "CNN, 7.2.2017. http://money.cnn.com/2017/02/07/media/ bill-oreilly-putin-killer-fox-news-trump/index.html (accessed 18/8/2017)

5 See: Dearden L." Alexander Litvinenko accused Vladimir Putin of a paedophile four months before he was poisoned.",Independent, 21/2/2016 http://www.independent.co.uk/ news/uk/crime/alexander-litvinenko-murdered-because-he-accused-putin-of-being-apaedophile-a6824806.html (accessed 18/8/2017) The same claims are repeated by the Washington Times a day later in the text:, Chasmar J. "Slain ex-KGB spy accused Putin of pedophilia 4 months before poisoning", http://www.washingtontimes.com/news/2016/ jan/22/alexander-litvinenko-slain-ex-kgb-spy-accused-putin /, (accessed 18/8/2017).

6 See : 'U.S. slams Russian 'barbarism' in Syria, Moscow says peace almost impossible", Reuters 25/ 9/ 2016 http://www.reuters.com/article/us-mideast-crisis-syria-un-usidUSKCN11V0NN (accessed on 18/8/2017)

7 See: "Theresa May expects full EU role until Brexit", BBC, 21.10.2016. http://www.bbc. com/news/uk-politics-37710786 (accessed 18/8/2017).

8 See: Norman J.,'What is behind Vladimir Putin's curious interest in Mount Athos?", Spectator, 10.9.2016. https://www.spectator.co.uk/2016/09/what-is-behind-vladimir-putins-curiousinterest-in-mount-athos/ (accessed 19/8/2017) 
However, the European Court has never convicted these abuses of the freedom of expression.

\section{Resolution of the European Parliament "EU Strategic Communication to Counteract Propaganda against it by Third Parties" and the derogation of the freedom of expression}

After 2014, Russophobia has become the dominant discourse in the Western media. (The EU also imposed economic sanctions to the RF). In that context, the European Court of Human Rights not only failed to convict the obvious inflaming of hate speech or Russophobia (mentioned in a few cases above), but they remained silent to the obvious attempt of violation of the freedom of expression and jeopardizing the public debate on the whole continent. The best-known example of derogation of the freedom of expression is the Resolution of the European Parliament on "EU Strategic Communication to Counteract Propaganda against it by Third Parties". This resolution is the first modern legal act adopted by an international subject which wrongfully restricts the freedom of expression on the European continent.

Namely, in November 2016, the European Parliament adopted the resolution "EU Strategic Communication to Counteract Propaganda against it by Third Parties". In the resolution initiated by a Polish MP Anna Fotyga, Russia is equalized with the terrorist Islamic state. Russia is allegedly waging a "hybrid war" in Ukraine, "does not share the values" of the European Convention on Human Rights and the UN International Covenant on Civil and Political Rights (even though Russia ratified those multilateral international agreements), "twists the truth", provokes "fear", "does not want a dialogue", represents itself as the only protector of "traditional Christian values", carries out "operations" through their secret services, helps political "extremists" and "populists", "falsifies history", leads a cyber campaign against the EU. ${ }^{9}$ At the end of the resolution, in the totalitarian manner, they even name the "unacceptable" Russian media such as RT and Sputnik.

The Resolution is obviously in legal collision with Article 10 of the European Convention on Human Rights and with Article 11 of the EU Charter of Fundamental Rights, which have guaranteed the freedom of expression and information on the European soil since 1953. It is also contradictory to the universal international

9 European Parliament resolution of 23 November 2016. on EU strategic communication to counteract propaganda against it by third parties, http://www.europarl.europa.eu/sides/ getDoc.do?type=TA\&reference $=$ P8-TA-2016-0441\&format $=$ XML\&language $=E N$ (accessed 19/8/2017) 
conventions such as the UN Charter, the Universal Declaration of Human Rights, and the UN International Covenant on Civil and Political Rights.

It was not surprising that the Resolution caused a lot of negative reactions, especially from the highest positions. The Russian President, commenting on such violation of the freedom of expression, remarked that the best way of communication would be an "open discussion" where "solid arguments" are presented, and not the prohibitions that are politically motivated.

On the other hand, Estonia, a EU member state, referred to the same Resolution of the European Parliament in 2017 when it prohibited the entrance of Russian journalists to this Baltic country. So, the Resolution of the European Parliament which is, in essence, a soft law or an auxiliary source of the international law (Avramov, Kreća, 2008: 68) is set above the primary sources of the international law for political reasons. Namely, a declaration (Bartoš, 1986: 56-67) is set above the international agreements (Kreća, 2012: 86), such as the European Convention of Human Rights, the Universal Declaration of Human Rights, and the UN International Covenant on Civil and Political Rights. To make the violation of legal norms even more absurd, in this way the EU also derogated their own primary right, i.e. the Charter of Fundamental rights of the EU which is legally binding for all the EU member states (Janjević, 2009: 317). Such an approach and the severe derogation of the hierarchy of the sources of the international law, as well as of the EU legislation cannot be explained by legal motives. Actually, they are not included in the Resolution of the European Parliament. The political motives were behind the adoption of the Resolution of the European Parliament. They have to be observed in the context of Russophobia which has become the dominant discourse in the western part of the European continent after 2014, as well as in the historical context. The Resolution named "EU Strategic Communication to Counteract Propaganda against it by Third Parties" is the continuation of Soviet-phobia from the period of the Cold War. The difference is that, at the time, the West tried to fight against Moscow by expanding the human rights on the continent, whereas now Western countries are restricting them for the same political goals. So, the observance and the territorial jurisdiction of the fundamental human rights, including the freedom of expression, are getting into a regressive phase at the beginning of the $21^{\text {st }}$ century.

\section{References}

Аврамов, С; Крећа. М., Међународно јавно право , Београд 2008

Бартош, М., Међународно уговорно право , Београд, 1986,

Јањевић, М., Конослидовани уговор о Европској унији ,2009 
Крећа, М.; Пауновић М. Практикум за међународно јавно право, Београд, 2002

Крећа, М., Међународно јавно право , Београд 2012

Маркузе, Х., Совјетски марксизам, Загреб, 1984

Маркузе, Х., Човијек једне димензије, Сарајево, 1989

Милисављевић, Б., Међународно обичајно право, Београд , 2016

Пауновић М., Кривокапић Б., Крстић И., Међународна људска права , Београд 2010:

Хански Р., Шајнин М., Најважнији случајеви пред Комитетом за људска права, Београд 2007

The European Convention on Human Rights (ECHR), 1950

European Parliament Resolution of 23 November 2016 on "EU strategic communication to counteract propaganda against it by third parties", European Parliament, accessed 19/8/2017, http://www.europarl.europa.eu/sides/getDoc. do?type $=$ TA\&reference $=P 8-T A-2016-0441 \&$ format $=X M L \&$ language $=E N$

Jersild v Denmark (App no 15890/89) ECHR 23 September 1994, European Court of Human Rights, http://www.hr-dp.org/files/2013/09/09/CASE_OF_ JERSILD_v._DENMARK_.pdf

Wiegrefe, Klaus, "NATO Efforts to Boost Force in Baltics Will Not Boost Security", Spiegel 12/07/2016, http://www.spiegel.de/international/world/nato-effortsto-boost-force-in-baltics-will-not-boost-security-a-1102578.html (accessed on 1/9/2017).

Lucas, E." We must stand up to Putin's gangster state.", The Times, 22/12/2016: https://www.thetimes.co.uk/article/we-must-stand-up-to-putins-gangsterstate-lclxflz9j; (accessed on 1/9/2017).

Bill O’Reilly, Bill: "Putin will have to wait for apology over 'killer' remark", CNN, 7.2.2017. http://money.cnn.com/2017/02/07/media/bill-oreilly-putin-killer-foxnews-trump/index.html (accessed 18/8/2017)

Dearden L."Alexander Litvinenko accused Vladimir Putin of a paedophile four months before he was poisoned.", Independent, 21/2/2016 http://www.independent.co.uk/news/uk/crime/alexander-litvinenko-murdered-because-heaccused-putin-of-being-a-paedophile-a6824806.html (accessed 18/8/2017)

Chasmar J. "Slain ex-KGB spy accused Putin of pedophilia 4 months before poisoning", the Washington Times, http://www.washingtontimes.com/news/2016/ 
jan/22/alexander-litvinenko-slain-ex-kgb-spy-accused-putin/, (accessed 18/8/2017).

Reuters 25/ 9/ 2016: 'U.S. slams Russian 'barbarism' in Syria, Moscow says peace almost impossible", http://www.reuters.com/article/us-mideast-crisis-syriaun-us-idUSKCN11V0NN (accessed 18/8/2017)

BBC, 21.10.2016: “Theresa May expects full EU role until Brexit", BBC, 21.10.2016. http://www.bbc.com/news/uk-politics-37710786 (accessed 18/8/2017).

Norman J.," What is behind Vladimir Putin's curious interest in Mount Athos? ", Spectator, 10.9.2016. https://www.spectator.co.uk/2016/09/what-is-behindvladimir-putins-curious-interest-in-mount-athos/ (accessed 19/8/2017)

\title{
Др Дејан Мировић,
}

Ванредни професор,

Правни факултет, Универзитет у Приштини - Косовска Митровица Косовска Митровица-Србија

\section{РЕЗОЛУЦИЈА ЕВРОПСКОГ ПАРЛАМЕНТА О СТРАТЕШКИМ КОМУНИКАЦИЈАМА У КОНТЕКСТУ ПРАВА НА СЛОБОДУ ИЗРАЖАВАЊА И РУСОФОБИЈЕ}

\begin{abstract}
Резиме
У новембру 2016. године Европски парламент је донео резолуцију „Стратешка комуникација ЕУу одбрани од пропаганде трећих страна“. У резолуцији коју је иницирала пољска посланица Ана Фотиг, Русија се изједначава са терористичком Исламском државом и у тоталитарном маниру се набрајају "неприхватљиви " руски медији попут RT и Спутњика. Резолуција је у правној колизији са чланом 10 Европске конвенције о људским правима и чланом 11 Повеље о основним правима ЕУ који гарантују слободу изражавања и информисања на европском тлу још од 1953. године. Она је и у супротности са универзалним међународним конвенцијама попут Повеље УН, Универзалне декларације о људским правима, и Међународног пакта о грађанским и политичким правима УН. Зато се она мора посматрати у контексту политички мотивисаних санкција које је УН увела против Руске Федерације 2014. године
\end{abstract} Кључне речи: Европски парламент, ЕУ, слобода изражавања, Руска Федерација. 